\title{
Phytochemical Screening and Antioxidant Activity Study of Methanol Extract of Stems and Roots of Codonopsis clematidea from Trans-himalayan Region
}

\author{
Pushpender Bhardwaj', Mohan Singh Thakur', Sahil Kapoor ${ }^{1}$, Ashwani Kumar Bhardwaj' , Ajay Sharma ${ }^{2}$, \\ Shweta Saxena' ${ }^{1}$, Om Prakash Chaurasia ${ }^{1}$, Raj Kumar ${ }^{1, *}$
}

\section{Pushpender Bhardwaj', Mohan Singh Thakur', Sahil Kapoor ${ }^{1}$, Ashwani Kumar Bhardwaj', Ajay Sharma², Shweta Saxena', Om Prakash Chaurasia ${ }^{1}$, Raj Kumar ${ }^{1, *}$}

\section{'Department of Medicinal Plant, Defence Institute of High-Altitude Research c/o 56 APO, INDIA. \\ ${ }^{2}$ Department of Chemistry, Sant Longowal Institute of Engineering and Technology, Longowal, Sangrur, Punjab-148106, INDIA.}

Correspondence

\section{Mr. Raj Kumar}

Department of Medicinal Plant, Defence Institute of High-Altitude Research c/o 56 APO, INDIA

Phone no : +91 8699222111

E-mail: rajdrdo08@gmail.com

History

- Submission Date: 18-12-2018;

- Review completed: 09-01-2019;

- Accepted Date: 11-04-2019

DOI : 10.5530/pj.2019.11.86

Article Available online

http://www.phcogj.com/v11/i3

\section{Copyright}

(c) 2019 Pharmacognosy Journal. This is an open-access article distributed under the terms of the Creative Commons Attribution 4.0 International license.

\begin{abstract}
Aim: The present report aimed to study the therapeutic and phytochemical properties of stems and roots of trans-himalayan plant Codonopsis clematidea. Material and Methods: The crude samples of stems and roots were explored for their chlorophyll, carotenoid and carbohydrate content in order to understand the matrix of these two plant parts. The extraction of phytochemicals was carried out by three different methods viz. sonication, maceration and soxhlet in methanol to identify the best extraction method. Further, analysis of Total Flavonoid Content (TFC) and Total Polyphenolic Content (TPC) were carried out using rutin trihydrate and gallic acid as a reference standard. Antioxidant capacity was estimated using three methods viz. 1,1-diphenyl-2-picrylhydrazyl (DPPH), 2,2'-azino-bis (3-ethylbenzothiazoline-6-sulphonic acid) (ABTS) radical scavenging assay and Ferric Reducing Antioxidant Power (FRAP) assay. In addition to this, GC-MS analysis was also performed for the identification of volatile constituents of Methanol Extract of Stems (MES) and Methanol Extract of Roots (MER). Results: The MES and Dimethylsulfoxide Extract of Stems (DES) were found to have higher Chlorophyll a $\left(\mathrm{Ch}_{\mathrm{a}}\right)$ content in comparison to Chlorophyll b $\left(\mathrm{Ch}_{\mathrm{b}}\right)$ and Carotenoids $\left(\mathrm{C}_{\mathrm{ca}}\right)$. Carbohydrate profile showed that stems and roots have the highest content of fructose in comparison to other sugar moieties. The soxhlet method showed the highest percentage extractive yield in the stems as well as roots. Results revealed that the MES showed higher antioxidant potential as compared to the MER. A correlation has also found to exist between the results of TPC, TFC and antioxidant assays, since TPC and TFC are key constituents responsible for the antioxidant potential. Conclusion: These results have been found to suggest the richness of MES in natural phenols, flavonoids and antioxidants. Further, study should be conducted over identification and characterization of compounds present in the extract.

Key words: Codonopsis clematidea, MES, MER, Fructose, Antioxidant, GC-MS.
\end{abstract}

\section{INTRODUCTION}

Since Vedic periods (500-1500 BC), the trans-Himalayan region has been found to have a prodigious ethnobotanical wealth specifically of medicinal plants. This cold desert region of Ladakh is located in the north most part of India $\left(65,000 \mathrm{~km}^{2}\right.$ area or more). The region is characterized by annual precipitation of 20-30 mm rainfall/snowfall with prolonged subzero temperature and during winters, the temperature may reach up to $-30^{\circ} \mathrm{C}$ at different localities of this vast, cold desert. The region is well known for its vast floral wealth. ${ }^{1-3}$ Rhodiola, Podophyllum, Artemisia, Rheum etc. are among the major medicinal plants which were previously studied and reported to have biologically relevant compounds that have valuable effects against the diseases like hypertension, stress, inflammation and tumor. ${ }^{4,5}$ The tremendous therapeutic potential of the flora is substantially due to bioactive second- ary metabolites found in these plants, which in turn credit the plants with tolerance to harsh climatic conditions in Ladakh. ${ }^{3}$ Campanulaceae family includes around 600 species of 40 genera and Codonopsis is one of the member in these genera. Codonopsis genus has been found with 42 species of perennial dicotyledonous herbaceous plants. Its predominant distribution is from central and eastern to southern Asia. Some species of this genus have been found to be used in various customary medicinal systems. ${ }^{6,7}$ The phytochemical studies of this genus have shown presence of major phytocomponents like alkaloids, phenylpropanoids, organic acid, triterpenoids, polyacetylene and polysaccharides. ${ }^{8-10}$

Codonopsis clematidea is one of the species of Codonopsis, reported in Ladakh region which is used in traditional medicinal systems of this region
Cite this article: Bhardwaj $P$, Thakur MS, Kapoor S, Bhardwaj AK, Sharma A, Saxena S, Chaurasia OP, Kumar R. Phytochemical Screening and Antioxidant Activity Study of Methanol Extract of Stems and Roots of Codonopsis clematidea from Trans-himalayan Region. Pharmacog J. 2019;11(3):536-46. 
(Amchi medicinal systems). This plant has been found to produce a pungent smell with bell-shaped flowers. Conventionally, it was therapeutically practiced against pathological conditions like stomach ache, leprosy, etc. ${ }^{11}$ Majorly effective against diseases related to heart, high blood pressure and also works as a tranquilizer. ${ }^{12}$ Its base has been found to be used in Codonopsis radix which is known as a substitute for Panax Ginseng. ${ }^{13}$

The imbalance in the production of Reactive Oxygen Species (ROS) and corresponding ROS mitigating antioxidants in human body cause oxidative stress that instigates the deterioration of biomolecules via oxidative damage, leading to the emergence of diseases such as diabetes, heart diseases, cancer, premature aging, inflammation, genotoxicity, arthritis and many more. ${ }^{14}$ Presence of one or more unpaired electrons is concomitant within normal or pathological metabolism of cells. Leakage of electrons from the electron transport chain in the process of cellular metabolism is concomitant to the production of ROS. Hydrogen peroxide $\left(\mathrm{H}_{2} \mathrm{O}_{2}\right)$, Hydroxyl radical (HO), Superoxide anion $\left(\mathrm{O}_{2}^{-}\right)$and Singlet oxygen $\left({ }^{1} \mathrm{O}_{2}\right)$ are the various ROS forms available in the environment. ${ }^{15}$ The normal process for aerobic respiration triggers polymorphonuclear cells (Leukocytes and macrophages) and peroxisomes which turn out to be the main factory for most endogenous oxidants produced by cells. Exogenous sources include ionizing radiations (e.g. UV-B), tobacco smoke, organic solvents, certain pollutants and pesticides. ${ }^{14,16,17}$ Antioxidant is a class of different compounds which can cut off the process of oxidation, by reacting with these free radicals, chelating catalytic metals and scavenging oxygen. ${ }^{18}$ Hence, antioxidants are of elite importance in inhibiting various diseases and pathophysiological dysfunctions. ${ }^{19}$ Some chemically synthesized antioxidants viz. tertbutylhydroquinone (TBHQ), Butylated Hydroxyanisole (BHA), Butylated Hydroxytoluene (BHT) and Propyl Gallate (PG) were reported to exert toxic effects. ${ }^{20}$ Therefore, there is a budding interest towards natural antioxidants from plant resources due to lesser undesirable effects. ${ }^{14,21}$

In the present study, we have investigated the stems and roots of Codonopsis clematidea for carbohydrate and chlorophyll content, yield efficacy, phytochemical analysis, total polyphenolic content, total flavonoid content, antioxidant activity and Gas Chromatography-Mass Spectrometry (GC-MS) analysis. To the best of our knowledge, there are no records demonstrating the above mentioned studies related to this plant of Ladakh. Hence, the present work would support for a better understanding of its chemical class of molecules which could be further isolated and also studies for their pharmacological relevance.

\section{MATERIALS AND METHODS}

\section{Flora collection}

Plant samples of Codonopsis clematidea were collected from Leh-Ladakh region in the month of June -July, 2015. Collection sites were Mulbek, a village of Suru and Padum village in Zanskar valley of Leh. The predominant vegetation of plant was near agriculture fields. Plant material identification and verification was done by Dr. O.P. Chaurasia, an ethnobotanist at Defence Institute of High-Altitude Research (DIHAR) of Defence Research and Development Organization (DRDO), Leh. The material was shade dried (15 days) and kibbled by an electric grinder and stored in a polyethylene bag at $4^{\circ} \mathrm{C}$. The moisture content of stems and roots was found $75.302 \pm 0.297$ and $84.035 \pm 2.140 \%$, respectively.

\section{Chemicals}

HPLC grade Dimethylsulfoxide (DMSO) and chloroform were purchased from RFCL limited (Rankem, India). HPLC grade methanol, gallic acid, sodium hydroxide and sodium nitrite were purchased from Merck (India). DPPH, ABTS, 2, 4, 6-tripyridyl-s-triazine (TPTZ), Folin-Ciocalteu (FC) reagent, Potassium Persulfate (PPS), aluminium chloride and different standards (Trolox, quercitin, inositol, arabitol, glucose, fructose and sucrose) were purchased from the Sigma Aldrich Pvt. Ltd (Switzerland). Rutin trihydrate and sodium carbonate were purchased from Himedia (India). The water for various analyses was used from the water purification (Merck Millipore Academic, United States of America (USA)) instrument. All other analytical grade solvents were purchased from Rankem, Loba Chemie and Qualigens Fisher Scientific.

\section{Analysis for Chlorophyll a ( $\left.\mathrm{Ch}_{a}\right)$, Chlorophyll b $\left(\mathrm{Ch}_{b}\right)$ and Carotenoid $\left(\mathrm{C}_{\mathrm{ca}}\right)$ content}

The chlorophylls and carotenoids were estimated in fresh stems of Codonopsis clematidea as demonstrated by Sumanta et al. (2014) and Porra et al. (1989) with few modifications. ${ }^{22,23}$ Fresh plant stems of 0.2 grams (g) were homogenized in homogenizer (IKA T 18 digital ULTRA-TURRAX, Germany) using $10 \mathrm{~mL}$ each of DMSO and methanol. The homogenized blend was centrifuged at 10,000 rpm for $15 \mathrm{~min}$ at $4^{\circ} \mathrm{C}$ (Heraeus multifuge X3R centrifuge, Thermo scientific). Further, $0.5 \mathrm{~mL}$ of supernatant was diluted with $4.5 \mathrm{~mL}$ of their respective solvent. The absorbance was measured at different wavelengths for $\mathrm{Ch}_{\mathrm{a}}, \mathrm{Ch}_{\mathrm{b}}$ and $\mathrm{C}_{\mathrm{ca}}$ by spectrophotometer (Thermo scientific Genesys 10S UV-Vis spectrophotometer, USA) and quantified by the equations mentioned in Table 1.

The moisture content (\%) was estimated using an oven drying method. ${ }^{24}$ The sample was dried and reduction in weight was expressed in percentage moisture content. The moisture content (\%) was taken into account by the following equation:

$$
\text { Moisture content }(\%)=\frac{\mathrm{FW}-\mathrm{DW}}{\mathrm{FW}} \times 100
$$

where, FW: fresh weight of the sample; DW: dry weight of the sample.

\section{Analysis for carbohydrate content}

Estimation of various carbohydrates in samples was carried by using ion exchange chromatography. For this, dried samples $(2.5 \mathrm{~g})$ of stems and roots were homogenized with a homogenizer at high speed using deionized water for one min respectively, followed by sonication in an ultrasonic bath (Ultrasonic cleaner YJ5120-1, India) at $40^{\circ} \mathrm{C}$ for $30 \mathrm{~min}$. The supernatant was diluted in distilled water and filtered by using a syringe filter $(0.22 \mu \mathrm{m})$. An injection volume of $20 \mu \mathrm{L}$ was used in column $(4.1 \mathrm{~mm} \times 250 \mathrm{~mm}$ RCX-307 $\mu \mathrm{m}-250 / 4.1 \mathrm{~mm}$; Hamilton, USA) with a flow rate of $1.0 \mathrm{~mL} / \mathrm{min}$ (930Compact IC flex Metrom; Switzerland) and mobile phase, consisting of $0.1 \mathrm{M} \mathrm{NaOH}$. Detection was performed by refractive index detector and results were expressed in $\mathrm{mg} / \mathrm{g}$ of dry sample.

\begin{tabular}{|c|c|}
\hline Solvents & Equations/Formula \\
\hline DMSO & $\begin{array}{c}\mathrm{Ch}_{\mathrm{a}}=12.47 \mathrm{~A}_{665.1}-3.62 \mathrm{~A}_{649.1} \\
\mathrm{Ch}_{\mathrm{b}}=25.06 \mathrm{~A}_{649.1}-6.5 \mathrm{~A}_{665.1} \\
\mathrm{C}_{\mathrm{ca}}=\left(1000 \mathrm{~A}_{480}-1.29 \mathrm{C}_{\mathrm{a}}-53.78 \mathrm{C}_{\mathrm{b}}\right) / 220\end{array}$ \\
\hline Methanol & $\begin{array}{c}\mathrm{Ch}_{\mathrm{a}}=16.72 \mathrm{~A}_{665.2}-9.16 \mathrm{~A}_{652.4} \\
\mathrm{Ch}_{\mathrm{b}}=34.09 \mathrm{~A}_{652.4}-15.28 \mathrm{~A}_{665.2} \\
\mathrm{C}_{\mathrm{ca}}=\left(1000 \mathrm{~A}_{470}-1.63 \mathrm{C}_{\mathrm{a}}-104.96 \mathrm{C}_{\mathrm{b}}\right) / 221\end{array}$ \\
\hline
\end{tabular}

$\mathrm{A}=$ Absorbance, $\mathrm{Ch}_{\mathrm{a}}=$ Chlorophyll $\mathrm{a}, \mathrm{Ch}_{\mathrm{b}}=$ Chlorophyll $\mathrm{b}, \mathrm{C}_{\mathrm{ca}}=$ Carotenoids. 


\section{Extraction and yield efficiency}

Isolation of key compounds from plants largely depends on different factors viz. extraction method, time, temperature, solvent, moisture content and particle size. Hence, to have a better yield a suitable extraction techniques is needed. ${ }^{25}$ Therefore, three extraction techniques viz. sonication, maceration and soxhlet were used to study the yield difference.

\section{Sonication}

Sonication extraction was carried out in Ultrasonicator at $40^{\circ} \mathrm{C}$ for $30 \mathrm{~min}$ (Ultrasonic cleaner YJ5120-1, India). Fifty grams of powdered sample (Stems and roots) was extracted three times by each time adding 1000 $\mathrm{mL}$ of solvent.

\section{Maceration}

Fifty grams pulverized sample was extracted three times by using $1000 \mathrm{~mL}$ (Each time) of solvent (Methanol) for $24 \mathrm{~h}$. The extraction was performed at room temperature $\left(\mathrm{RT} ; 25^{\circ} \mathrm{C}\right)$ in dark conditions.

\section{Soxhlet}

The pulverized samples $(50 \mathrm{~g})$ were extracted with $1000 \mathrm{~mL}$ of methanol for $3 \times 12 \mathrm{~h}$. The extraction was done at the boiling point of the respective solvent.

All these extracts were further filtered by Whatman filter paper grade 1 . Filtered extract was concentrated by using rotavapor (Buchi R-215, Switzerland) at a temperature of $50^{\circ} \mathrm{C}$ and lyophilized (Labconco FreeZone 4.5plus, USA) at $-80^{\circ} \mathrm{C}$ and 0.050 mbar pressures and stored in $4{ }^{\circ} \mathrm{C}$ till further analysis.

The yield efficiency of the dried extract was calculated by using following equation:

$$
\text { Yield }(\%)=\frac{\text { Amount of extract }}{\text { Amount of sample }} \times 100
$$

The extract with maximum yield was further studied for various parameters.

\section{Preliminary phytochemical tests}

The different phytochemical tests were performed as described by various standard books and research papers to identify the existence of different classes of compounds viz. alkaloids, glycosides, proteins, phenols, carbohydrates, diterpenoids, triterpenoids and flavonoids using standard qualitative tests. ${ }^{26}$ The results were represented as + or - which indicate the presence or absence of classes of compounds in the extracts.

\section{Total polyphenolic content}

The assessment of the polyphenolic content of extracts was determined by FC reagent method with some modifications. ${ }^{27}$ Fifty micro liters of different concentrations of standard solution (Gallic acid; 5.000-160.000 $\mu \mathrm{g} / \mathrm{mL}$ ) and extracts were mixed with $450 \mu \mathrm{L}$ of deionized water respectively, followed by addition of FC reagent $(50 \mu \mathrm{L})$ and incubated at RT for $5 \mathrm{~min}$. Further, $100 \mu \mathrm{L}$ of sodium carbonate solution (20\%) was added to each reaction mixture and incubated in dark conditions for $60 \mathrm{~min}$ at RT. After incubation, absorbance of the samples and standard was measured spectrophotometrically (Molecular devices UV-Visible SpectraMax i3x Spectrophotometer, USA) at $750 \mathrm{~nm}$. Results were expressed in $\mathrm{mg}$ of Gallic Acid Equivalent (GAE)/ g of Dry Powder Extract (DPE). The total phenolic content of samples was calculated by the following formula

$$
\mathrm{C}=\frac{\mathrm{c} \times \mathrm{v}}{\mathrm{m}}
$$

where: $\mathrm{C}=$ total phenolic content in $\mathrm{mg} \mathrm{GAE} / \mathrm{g}$ dry powdered extract, $\mathrm{c}=$ concentration of reference standard in $\mathrm{mg} / \mathrm{mL}$ obtained from calibration curve, $\mathrm{v}=$ volume of extract in $\mathrm{mL}, \mathrm{m}=$ mass of extract in gram. ${ }^{26}$

\section{Total flavonoids content}

The flavonoid content was evaluated by aluminium chloride method with slight modifications. ${ }^{26}$ One hundred fifty micro liters of different concentrations of standard solution (Rutin trihydrate; 3.906-2000.000 $\mu \mathrm{M}$ ) and two extracts were mixed with $600 \mu \mathrm{L}$ of deionized water respectively, followed by addition of $45 \mu \mathrm{L}$ of sodium nitrite solution $(0.724 \mathrm{M})$ and incubated for $5 \mathrm{~min}$ at RT. Successively, $45 \mu \mathrm{L}$ of aluminium chloride $(0.749$ $\mathrm{M})$ was added to each reaction mixture and incubated for $6 \mathrm{~min}$.Further, $300 \mu \mathrm{L}$ of sodium hydroxide $(1 \mathrm{M})$ was added to each reaction mixture. Total reaction volume was made to $1500 \mu \mathrm{L}$ by addition of $360 \mu \mathrm{L}$ deionized water. Finally, the absorbance was noted at $510 \mathrm{~nm}$ using spectrophotometer. The results were expressed in $\mu \mathrm{M}$ of rutin trihydrate equivalent $(\mathrm{RE}) / \mathrm{g}$ of DPE.

\section{Antioxidant activity DPPH assay}

The DPPH radical scavenging activity of extracts was determined by the procedure mentioned by Bhardwaj et al. (2016) with some modifications. ${ }^{28}$ $0.004 \%$ of DPPH (in methanol) and extracts (MES: $0.062-4.000 \mathrm{mg} / \mathrm{mL}$; MER: $0.400-120.000 \mathrm{mg} / \mathrm{mL}) /$ standard $(0.590-302.236 \mu \mathrm{g} / \mathrm{mL})$ were mixed in the ratio of 1:15 using vortex and kept for $30 \mathrm{~min}$ in the dark at RT. After incubation, absorbance was measured by spectrophotometer at $517 \mathrm{~nm}$. Quercetin (QR) was used as a reference standard. The ability to scavenge radicals was estimated by the following equation:

$$
\text { Radical scavenging activity }(\%)=\frac{A_{\text {control }}-A_{\text {sample }}}{A_{\text {control }}} \times 100
$$

where, $\mathrm{A}_{\text {control }}$ : absorbance of DPPH radical in methanol; $\mathrm{A}_{\text {sample }}$ : absorbance of DPPH radical with extracts/standard.

Further, $\mathrm{IC}_{50}$ (Half-maximal inhibitory concentration), $\mathrm{EC}_{50}$ (Amount of antioxidant required to decrease the initial DPPH concentration by $50 \%$ ), ARP (Antiradical power) and Quercetin equivalent antioxidant capacity (QEAC) of scavengers were determined. ${ }^{29}$ The $\mathrm{IC}_{50}$ value was calculated by plotting the logarithm of sample concentration versus scavenging capacity. The $\mathrm{EC}_{50}$ was calculated by using equation

$$
\mathrm{EC}_{50}=\mathrm{IC}_{50} /(\mathrm{DPPH}) \text { in } \mathrm{mg} / \mathrm{mL}
$$

The ARP was also determined as following equation

$$
\operatorname{ARP}=\left(1 / \mathrm{EC}_{50}\right) \times 100
$$

The results were also expressed as QEAC using the following equation

$$
\mathrm{QEAC}=\left(\mathrm{IC}_{50(\mathrm{QR})} / \mathrm{IC}_{50 \text { (sample })}\right) \times 10^{5}
$$

\section{ABTS assay}

ABTS radical scavenging activity was performed as explained by Dhar et al. (2013) with few modifications. ${ }^{29}$ ABTS stock solution was prepared using equal volume ( $1 \mathrm{~mL}$ each) of $7 \mathrm{mM}$ ABTS solution and $2 \mathrm{mM}$ PPS solution followed by incubation for $12 \mathrm{~h}$ at RT. Working solution was prepared by mixing $1 \mathrm{~mL}$ of the incubated stock solution with $22 \mathrm{~mL}$ of water resulting into an absorbance of $0.702 \pm 0.002$ at $734 \mathrm{~nm}$ using spectrophotometer. Four hundred micro liters of different concentration of standard (QR; $0.018-37.780 \mu \mathrm{g} / \mathrm{mL}$ ) and extracts (MES: 1.953 - $1000.000 \mu \mathrm{g} / \mathrm{mL}$; MER: $31.250-4000.000 \mu \mathrm{g} / \mathrm{mL}$ ) were allowed to react with $400 \mu \mathrm{L}$ of the $\mathrm{ABTS}^{+}$solution respectively. After 7 min of incubation, 
absorbance was measured spectrophotometrically at $734 \mathrm{~nm}$. The scavenging percentage, $\mathrm{IC}_{50}, \mathrm{EC}_{50}, \mathrm{ARP}$ and QEAC were calculated as mentioned previously in the DPPH assay.

\section{FRAP assay}

The assay was carried out for different extracts as demonstrated by Lim et al. (2013) with slight modifications. ${ }^{30}$ Three hundred millimolar of acetate buffer ( $p \mathrm{H} 3.6), 20 \mathrm{mM}$ TPTZ solution $(40 \mathrm{mM} \mathrm{HCl})$ and $20 \mathrm{mM}$ $\mathrm{FeCl}_{3}$ (Water) were mixed together in the ratio of 10:1:1 to make FRAP solution and tested against extracts (MES: $1.000 \mathrm{mg} / \mathrm{mL}$; MER: 10.000 $\mathrm{mg} / \mathrm{mL}$ ) by allowing it to react with the FRAP solution in the ratio of 1:30 for $30 \mathrm{~min}$ in dark at $37^{\circ} \mathrm{C}$. The blue colored product (Ferrous tripyridyltriazine complex) was formed and absorbance was taken at $593 \mathrm{~nm}$ spectrophotometrically. Trolox $(0.009-1.200 \mathrm{mM})$ was used as a reference standard and results were expressed $\mu \mathrm{M}$ of trolox equivalent (TE)/g of DPE.

\section{GC-MS analysis}

The GC-MS analysis of the methanol extracts was performed to determine the components present in the extracts by using method mentioned by Sharma et al. (2016) with modification. ${ }^{31}$ One micro liter of the sample $(5 \mathrm{mg} / \mathrm{mL})$ was injected in GC (Gas chromatography systems GC-2010 Plus, Shimadzu) coupled with mass spectrometer (GC-MS-QP 2010 Ultra). The program of oven temperature starts with the initial temperature at $80^{\circ} \mathrm{C}$ with a hold time of $1 \mathrm{~min}$ and increased at the rate of $4^{\circ} \mathrm{C} / \mathrm{min}$ up to $236^{\circ} \mathrm{C}$, followed by hold for $5 \mathrm{~min}$ and final increase to $300^{\circ} \mathrm{C}$ at the rate of $5^{\circ} \mathrm{C} / \mathrm{min}$. The flow rate of carrier gas (Helium) was $1 \mathrm{~mL} / \mathrm{min}$ with a split ratio of 1: 5 . The temperatures of injection port, ion source and interface were 280,290 and $200^{\circ} \mathrm{C}$ respectively. The samples were scanned between the mass range of $40 \mathrm{~m} / \mathrm{z}$ to $800 \mathrm{~m} / \mathrm{z}$ with Electron ionization (EI) mode. The identification of various components was carried out mainly by a comparison of their retention time and mass spectral data with that of retention time and mass spectral database of Wiley and NIST library. The compounds quantified on the basis of area under peak and results were expressed in percentage area.

\section{Statistical analysis}

All the experimental results were presented as the mean \pm Standard Deviation (SD) and all experiments were performed in triplicate. One-way ANOVA (Analysis of variance) with Duncan's multiple range tests and independent t-test was used in SPSS 17.0 (Statistical Program for Social Sciences, SPSS Corporation, Chicago, IL) to determine the significance of results. The $\mathrm{IC}_{50}$ values were measured accurately by non linear regression analysis using log concentration range of these extracts in GraphPad Prism5. The probability $(p)$ value $\leq 0.05$ was considered significant for ANOVA and the marked correlations among the different assays. The results were processed with the help of computer programmes viz. MS Excel and GraphPad Prism 5.

\section{RESULTS}

\section{Analysis of chlorophylls and carotenoids content}

In the present study, chlorophylls and carotenoids content of methanol and DMSO extract of stems and roots were determined as illustrated in Table 2. $\mathrm{Ch}_{\mathrm{a}}$ and $\mathrm{Ch}_{\mathrm{b}}$ concentration in MES was found to be $0.584 \pm 0.010$ and $0.244 \pm 0.053 \mu \mathrm{g} / \mathrm{mL}$, respectively whereas in DES, $0.763 \pm 0.038$ and $0.211 \pm 0.032 \mu \mathrm{g} / \mathrm{mL}$ of $\mathrm{Ch}_{\mathrm{a}}$ and $\mathrm{Ch}_{\mathrm{b}}$ content was observed. The content of carotenoids was $0.273 \pm 0.028$ and $0.287 \pm 0.023 \mu \mathrm{g} / \mathrm{mL}$ in DES and MES, respectively.
Table 2: Chlorophyll and carotenoids content in stems and roots of Codonopsis clematidea.

\begin{tabular}{ccccc}
\hline \multicolumn{4}{c}{ Chlorophyll and carotenoid content } \\
\hline & \multicolumn{2}{c}{ Stems } & \multicolumn{2}{c}{ Roots } \\
\hline Pigments & DES & MES & DER & MER \\
\hline $\mathrm{Ch}_{\mathrm{a}}$ & $0.763 \pm 0.038^{\mathrm{b}}$ & $0.584 \pm 0.010^{\mathrm{b}}$ & $\mathrm{NQ}$ & $\mathrm{NQ}$ \\
$\mathrm{Ch}_{\mathrm{b}}$ & $0.211 \pm 0.032^{\mathrm{a}}$ & $0.244 \pm 0.053^{\mathrm{a}}$ & $\mathrm{NQ}$ & $\mathrm{NQ}$ \\
$\mathrm{C}_{\mathrm{ca}}$ & $0.273 \pm 0.028^{\mathrm{a}}$ & $0.287 \pm 0.023^{\mathrm{a}}$ & $\mathrm{NQ}$ & $\mathrm{NQ}$ \\
$\mathrm{Ch}_{\mathrm{a}+\mathrm{b}}$ & $0.974 \pm 0.068$ & $0.828 \pm 0.063$ & $\mathrm{NQ}$ & $\mathrm{NQ}$ \\
$\mathrm{Ch}_{\mathrm{a}} / \mathrm{Ch}_{\mathrm{b}}$ & $3.653 \pm 0.423$ & $2.465 \pm 0.525$ & $\mathrm{NQ}$ & $\mathrm{NQ}$ \\
$\mathrm{Ch}_{\mathrm{a}+\mathrm{b}} / \mathrm{C}_{\mathrm{ca}}$ & $3.600 \pm 0.436$ & $2.898 \pm 0.332$ & $\mathrm{NQ}$ & NQ \\
\hline
\end{tabular}

$\mathrm{NQ}=$ Not quantified, Values are means $\pm \mathrm{SD}$ of three determinations. The values having different superscript (Small alphabet) letters within a column were significantly different $(p \leq 0.05)$.

Table 3: Sugar profile $(\mathrm{mg} / \mathrm{g})$ of stems and roots of Codonopsis clematidea.

\begin{tabular}{ccc}
\hline Carbohydrate & Stems & Roots \\
\hline Inositol & $1.103 \pm 0.043^{\mathrm{a}}$ & $1.322 \pm 0.118^{\mathrm{a}}$ \\
Arabitol & $0.394 \pm 0.004^{\mathrm{a}}$ & $\mathrm{NQ}$ \\
Glucose & $12.881 \pm 1.620^{\mathrm{b}}$ & $2.680 \pm 0.072^{\mathrm{a}}$ \\
Fructose & $13.595 \pm 0.435^{\mathrm{b}}$ & $51.127 \pm 1.453^{\mathrm{c}}$ \\
Sucrose & $\mathrm{NQ}$ & $38.915 \pm 3.290^{\mathrm{b}}$ \\
\hline
\end{tabular}

$\mathrm{NQ}=$ Not quantified, Values are means $\pm \mathrm{SD}$ of three determinations. The values having different superscript (Small alphabet) letters within a column were significantly different $(p \leq 0.05)$.

\section{Analysis of carbohydrates content}

The carbohydrates (inositol, arabitol, glucose, sucrose and fructose) were estimated with the help of ion exchange chromatography. The content of different carbohydrates evaluated in stems and roots ranged from $0.394 \pm 0.004$ to $51.127 \pm 1.453 \mathrm{mg} / \mathrm{g}$. In stems, the concentration of different identified sugars was observed as $1.103 \pm 0.043 \mathrm{mg} / \mathrm{g}$ (Inositol), $0.394 \pm 0.004 \mathrm{mg} / \mathrm{g}$ (Arabitol), $12.881 \pm 1.620 \mathrm{mg} / \mathrm{g}$ (Glucose) and $13.595 \pm 0.435 \mathrm{mg} / \mathrm{g}$ (Fructose), respectively. Whereas, in case of roots, fructose was found to have highest concentration i.e. $51.127 \pm 1.453 \mathrm{mg} / \mathrm{g}$ followed by sucrose $(38.915 \pm 3.290 \mathrm{mg} / \mathrm{g})$, glucose $(2.680 \pm 0.072 \mathrm{mg} / \mathrm{g})$ and inositol $(1.322 \pm 0.118 \mathrm{mg} / \mathrm{g})$, respectively (Table 3 ).

\section{Extract yield (\%)}

In the present study, the yield percentage of MES and MER was determined by applying three different extraction techniques viz. soxhlet, sonication and maceration extraction. The efficacy of extraction for different extracts was found to vary from $9.150 \pm 0.837$ to $34.139 \pm 1.809 \%$. In MER highest yield percentage was achieved by using soxhlet method $(34.139 \pm 1.809 \%)$ followed by maceration $(30.997 \pm 0.875 \%)$ and sonication $(28.562 \pm 1.297 \%)$, respectively. However, in MES yield percentage of $18.732 \pm 0.834 \%, 11.846 \pm 0.372 \%$ and $9.150 \pm 0.837 \%$ in soxhlet, maceration and sonication were achieved, respectively (Table 4). On the basis of yield (\%), soxhlet was identified as the best technique for extraction which selected for further analysis.

\section{Phytochemical screening tests}

The phytochemical screening tests were performed to identify the presence and absence of diverse categories of compounds present in MES and MER. Here, both MES and MER have indicated the presence of sugar, protein, glycosides, triterpenoids and steroids except alkaloids 
Bhardwaj et al.: Phytochemistry of Codonopsis clematidea's Stems and Roots Methanol Extract

Table 4: Yield (\%) of MES and MER of Codonopsis clematidea.

\begin{tabular}{ccc}
\hline Yield (\%) & MES & MER \\
\hline Maceration & $11.846 \pm 0.372^{*}$ & $30.997 \pm 0.875^{\circledR}$ \\
Sonication & $9.150 \pm 0.837^{\circledR}$ & $28.562 \pm 1.297^{\circledR}$ \\
Soxhlet & $18.732 \pm 0.834^{*}$ & $34.139 \pm 1.809^{*}$ \\
\hline
\end{tabular}

$\mathrm{NQ}=$ Not quantified, Values are means $\pm \mathrm{SD}$ of three determinations. The values having different superscript (Special character) letters within a column were significantly different $(p \leq 0.05)$.

Table 5: Phytochemical test results of MES and MER of Codonopsis clematidea.

\begin{tabular}{ccc}
\hline Qualitative tests & MES & MER \\
\hline Carbohydrates & + & + \\
Protein & + & + \\
Glycoside & + & + \\
Alkaloids & + & - \\
Flavonoid & + & - \\
Triterpenoid & + & + \\
Steroids & + & + \\
\hline
\end{tabular}

$+=$ Present, $-=$ Absent

and flavonoids which were found absent in roots and results are given Table 5.

\section{Total polyphenol and Total flavonoid content}

The polyphenol content of MES and MER was determined and listed in Table 6. MES had found to contain higher polyphenolic concentration (58.821 $\pm 3.780 \mathrm{mg}$ of GAE/g of DPE) in comparison to MER, where $7.258 \pm 0.228 \mathrm{mg}$ of GAE/g of DPE of polyphenolic content has been estimated. A similar trend was also found in case of flavonoid content, where $157.444 \pm 6.882 \mu \mathrm{M}$ of RE/g of DPE of flavonoid was observed in MES whereas; $14.606 \pm 0.267 \mu \mathrm{M}$ of RE/g of DPE was obtained in MER.

\section{Antioxidant activity \\ DPPH assay}

Free radical scavenging capacity of the MES and MER of Codonopsis clematidea was evaluated with their ability to scavenge radicals produced by DPPH. The DPPH radical scavenging capacity of MES and MER was $48.516 \pm 1.790$ and $8.121 \pm 2.900 \%$ at $1000 \mu \mathrm{g} / \mathrm{mL}$ respectively. A similar pattern was found for $\mathrm{IC}_{50}, \mathrm{EC}_{50}$ and $\mathrm{ARP}$ value. The $\mathrm{IC}_{50}, \mathrm{EC}_{50}$ and $\mathrm{ARP}$ value of MES were found to be $1.007 \mathrm{mg} / \mathrm{mL}, 25.175 \mathrm{mg} / \mathrm{mg}_{\mathrm{DPPH}}$ and 3.972 whereas for MER $29.475 \mathrm{mg} / \mathrm{mL}, 736.875 \mathrm{mg} / \mathrm{mg}_{\mathrm{DPPH}}$ and 0.136 , respectively. QR was used as reference standard which showed $96.080 \pm 0.264$ $\%$ inhibition at $302.236 \mu \mathrm{g} / \mathrm{mL}$, which is significantly higher than stems and roots. The QEAC value for stems and roots was found to be 3177.756 and 108.567.

\section{ABTS assay}

The ABTS radical scavenging capacity (\%) of MES and MER of Codonopsis clematidea were analyzed with $\mathrm{QR}$ as a positive control. The scavenging capacity of extracts has shown similar trend as shown in DPPH assay. The percentage inhibition of MES and MER was observed as $85.272 \pm 5.446$ and $7.488 \pm 0.988 \%$ respectively at a concentration of $62.50 \mu \mathrm{g} / \mathrm{mL}$ (Table 8 ). The extracts and reference standard inhibited the radicals of ABTS in a dose dependent manner. The concentration of samples at which it show $50 \%$ scavenging $\left(\mathrm{IC}_{50}\right)$ of ABTS radical was found to be 0.029 and 0.814 $\mathrm{mg} / \mathrm{mL}$, respectively. The $\mathrm{EC}_{50}$ and $\mathrm{ARP}$ values for MES were observed as
Table 6: TPC, TFC and FRAP values of MES and MER of Codonopsis clematidea.

\begin{tabular}{ccc}
\hline & MES & MER \\
\hline TPC(mg of GAE /g of DPE) & $58.821 \pm 3.780^{* *}$ & $7.258 \pm 0.228$ \\
TFC ( $\mu$ M of RE/g of DPE) & $157.444 \pm 6.882^{* * *}$ & $14.606 \pm 0.267$ \\
FRAP (mM of TE/g of DPE) & $0.485 \pm 0.076^{* *}$ & $0.040 \pm 0.007$ \\
\hline
\end{tabular}

Values are means \pm SD of three determinations. Independent T-test analysis for TPC, TFC and FRAP values and significant at ${ }^{* *} p \leq 0.001$ and ${ }^{* *} p \leq 0.01$ with row.

$0.372 \mathrm{mg} / \mathrm{mg}_{\mathrm{ABTS}}$ and 269.151 whereas; for MER $10.436 \mathrm{mg} / \mathrm{mg}_{\mathrm{ABTS}}$ and 9.582, respectively. The QEAC value has also followed the same pattern and found to as 2001.380 and 71.253 respectively.

\section{FRAP assay}

The ability of the plant extracts to reduce the TPTZ-Fe (III) complex was determined using the FRAP assay. An antioxidant rich extract capable of donating a single electron to the ferric-TPTZ (Fe (III)-TPTZ) complex would lead to the reduction of this complex into the blue colored complex (Ferrous-TPTZ (Fe (II)-TPTZ)). This complex shows strong absorbance at $593 \mathrm{~nm}$. The MES and MER have shown $0.485 \pm 0.076$ and $0.040 \pm 0.007 \mathrm{mM}$ of TE/g of DPE, respectively. The FRAP values for MER was found significantly lower than that of MES and their potential to reduce the TPTZ-Fe (III) complex has been listed in Table 6 .

\section{Correlation}

The correlation coefficients ( $r$ ) between ABTS, DPPH, FRAP, TPC and TFC has been summarized in Table 9. DPPH, ABTS and FRAP showed a significant positive correlation of $0.988,0.991$ and 0.961 with TPC. In case of TFC, positive correlation values was observed similar to TPC, with other assays i.e. 0.993 (DPPH), 0.991 (ABTS) and 0.984 (FRAP) was the value of correlation. A good correlation was also observed between TPC and TFC (0.994). Analysis of correlation concludes that the antioxidant and free radical scavenging activity may be the result of phenol and flavonoid molecules present in MES and MER of Codonopsis clematidea.

\section{GC-MS}

In the present investigation, GC-MS was used to examine various volatile constituents present in MES and MER of Codonopsis clematidea. MES and MER obtained using the soxhlet extraction showed the presence of 41 and 34 compounds respectively however; only 28 for MES and 20 for MER were identified having S.I. index $\geq 80 \%$. Majority of compounds which were found in these two extracts were of fatty acids and terpenoids origin whereas, quinic acid derivative, cycloartanol derivative, tocopherol derivative, phenols, alkane, hydroxypyrimidine, alcohol, alkaloid, cyclic diketone, aldehyde, alkyl halide, stigmastane and long chain hydrocarbons classes of secondary metabolites were also identified (Table 10). The structures of identified compounds have been given in Figure 2 and 3.

\section{DISCUSSION}

Leh-Ladakh is a region of India where temperature reaches to $-30^{\circ} \mathrm{C}$ in winters. Beside such harsh environmental conditions, approximately 1100 species of medicinal plants have been reported in this region. ${ }^{1}$ Therefore, Ladakh Himalayas which seems barren and devoid of vegetation is very rich in medicinally important herbs. Chlorophylls $\left(\mathrm{Ch}_{\mathrm{a}}\right.$ and $\left.\mathrm{Ch}_{\mathrm{b}}\right)$ are major pigments of Photosystem 1 (PS1) and Photosystem 2 (PS2) for harnessing light energy and converting it into chemical energy. $\mathrm{Ch}_{\mathrm{b}}$ is an accessory pigment that transfers absorbed light to reaction centre of $\mathrm{Ch}_{\mathrm{a}}$, resulting to enhancement of photosynthesis efficacy. ${ }^{22,32,33}$ In present study, it has been found that DES and MES have higher 
content of $\mathrm{Ch}_{\mathrm{a}}$ in comparison to $\mathrm{Ch}_{\mathrm{b}}$ and their ratio is also high (Table 2). This clearly suggests that, higher exposure of light has increased the $\mathrm{Ch}_{\mathrm{a}}$ suggesting the major role in photosynthesis at high altitude whereas, $\mathrm{Ch}_{\mathrm{b}}$ was found low as it shows a major role of increasing the absorbance of light at shade or low light conditions. ${ }^{34}$ Various literatures also suggest the existence of considerable differences in the content of PS1 and PS2 because of the change in environment light condition which also visible in chloroplast's grana and stroma lamellae regions of plant cells. ${ }^{35,36}$ Carotenoids are another class of accessory pigments which play an important role in protection of chlorophyll from photodamage and also have antioxidant properties. ${ }^{37,38}$ In this study, MES and DES have shown low content of $\mathrm{C}_{\mathrm{ca}}$ in comparison to $\mathrm{Ch}_{\mathrm{a}}$ however, $\mathrm{C}_{\mathrm{ca}}$ content has been found significantly similar to $\mathrm{Ch}_{\mathrm{b}}$. Further, ratio between chlorophylls $\left(\mathrm{Ch}_{\mathrm{a}+\mathrm{b}}\right)$ and $\mathrm{C}_{\mathrm{ca}}$ has been found higher in the case of DES in comparison to MES.

Carbohydrates, being a major energy source have also been found to play a key role in biotic stress. ${ }^{39}$ Thus, there is a greater demand to understand the carbohydrate profile of plants. In present study roots were found to contain higher content of fructose and sucrose whereas; stems were found to be rich in glucose and fructose. It is apparent from these results that overall sugar content of roots was higher in comparison to stems and therefore, roots can be a potential source of carbohydrates.

Extraction is an important step involved in isolation and identification of bioactive ingredients from plants. Currently, conventional extraction techniques such as maceration and soxhlet have been used along with several new approaches viz. ultrasonic extraction, microwave-assisted extraction and accelerated solvent extraction, to increase the focal ratio of bioactive components in extract. ${ }^{40}$ Several published studies have been found to indicate a variation in bioactive component's cluster with respect to different extraction techniques. Thus, there is a need to emphasize on the model of extraction technique. ${ }^{41}$ Table 4 illustrates the yield percentage of MES and MER with three different extraction techniques viz. soxhlet, sonication and maceration. In the current study maximum yield (\%) was obtained in soxhlet technique in both MES and MER. Further, higher yield (\%) was found in case of MER as in comparison to MES. Soxhlet extraction produced the maximum yield as it reduces the viscosity and surface tension of the solvents at high temperature leading to higher perforation of solvent and increases the extraction efficacy of solvents. ${ }^{26}$ Though the yield percentage of sonication is lower to maceration the efficacy of sonication is more than maceration technique which can be the effect of acoustic cavitation phenomenon of sonication waves due to which the cell wall disrupts and allows the solvent to penetrate deeply. ${ }^{42}$

Phenols are found to be the most widely spread secondary metabolites in the plant kingdom with great recognition as potential natural antioxidants since they were found to have the ability to act as an efficient radical scavenger, metal chelator, reducing agent, singlet oxygen quencher, a hydrogen donor and in other activities of the plant which are associated with the redox properties of these components. The present results of our study are in good agreement with previous studies which have shown a positive correlation between TPC, TFC and antioxidant capacities of plant extracts. ${ }^{43-46}$ Similarly, flavonoids are also well known for their antioxidant properties due to availability of $\mathrm{OH}$ groups in them. ${ }^{45,47,48} \mathrm{In}$ this study, MES is found to possess high TPC and TFC leading to higher antioxidant activity in comparison to MER (Table 6). Thus, there is a need to study and identify the polyphenol and flavonoid components present in the extract. In addition to this, phytochemical tests also correlate with the TPC and TFC results demonstrating the presence of carbohydrate, protein, glycosides, triterpenoids and steroids in MES and MER except flavonoids and alkaloids which were found to be absent in MER (Table 5).

Many medicinal floras are well recognized for their robust action as antioxidants and their ability to scavenge free radicals. This power of medicinal plants and their extracts to scavenge free radicals depend on the kind of ROS. The DPPH assay is a simple and accurate method to evaluate the antioxidant capacity of plant extracts where the stable free radicals of DPPH are used to determine the antioxidant capacity in addition to ABTS and FRAP. ${ }^{29,49,50}$ The analysis of MES and MER of Codonopsis clematidea for their antioxidant and free radical scavenging activity are listed in Table 6, 7 and 8 and found in a good correlation with TPC and TFC values. MES, which has a higher TPC and TFC values show higher DPPH, ABTS and FRAP activity. The results of ABTS had revealed the same phenomenon as reported in the DPPH assay. The $\mathrm{IC}_{50}$ values were measured accurately by using log conc. range of these extracts (Figure 1). Similarly, the ferric reducing ability in studied extracts has followed a homologues trend to DPPH, ABTS, TPC and TFC where MES have a better response than MER. This substantial divergence between the activities of both samples clearly signifies better performance of MES as antioxidant in comparison to MER, thus can be supplemented as an antioxidant source.

\section{DPPH}

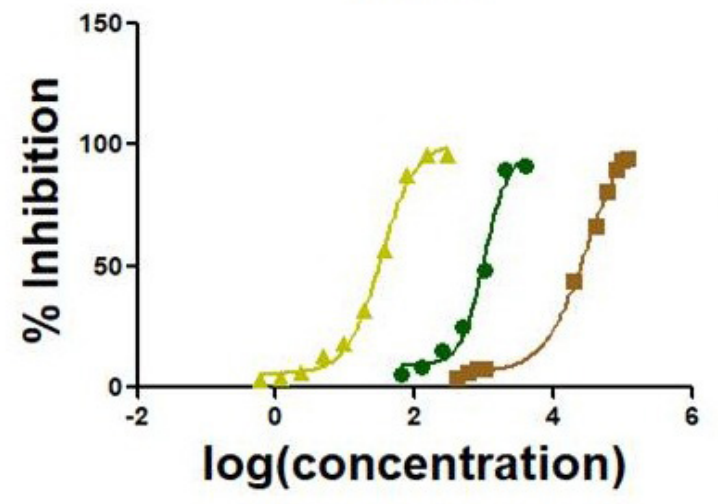

ABTS

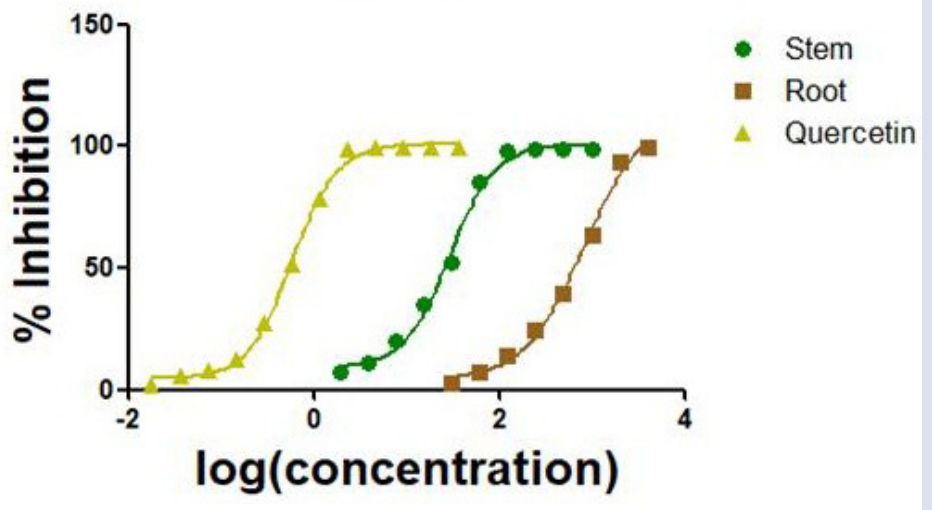

Figure 1: Graph showing DPPH and ABTS activity of MES, MER and Quercitin. 
Table 7: Analysis of \% inhibition in DPPH, IC $\mathrm{I0}_{5 \mathrm{mg} / \mathrm{mL})}, \mathrm{EC}_{50(\mathrm{mg} / \mathrm{mgDPPH}),} A R P$, QEAC values of MES and MER of Codonopsis clematidea.

\begin{tabular}{cccccc}
\hline Sample & $\begin{array}{c}\% \text { Inhibition at } \\
1000 \mu \mathrm{g}\end{array}$ & $\mathrm{IC}_{50(\mathrm{mg} / \mathrm{mL})}$ & $\mathrm{EC}_{50(\mathrm{mg} / \mathrm{mg} \mathrm{DPH})}$ & ARP & QEAC \\
\hline \multicolumn{5}{c}{$\mathrm{DPPH}$} \\
MES & $48.516 \pm 1.790^{\mathrm{b}}$ & 1.007 & 25.175 & 3.972 & 3177.756 \\
MER & $8.121 \pm 2.900^{\mathrm{a}}$ & 29.475 & 736.875 & 0.136 & 108.567 \\
QR & $96.080 \pm 0.264^{\mathrm{c} \&}$ & & & & \\
\hline
\end{tabular}

$\&=\%$ inhibition at $302.236 \mu \mathrm{g} / \mathrm{mL}$. The values having different superscript (Small alphabet) letters within a column were significantly different $(p \leq 0.05)$.

Table 8: Analysis of \% inhibition in ABTS, IC QEAC values of MES and MER of Codonopsis clematidea.

\begin{tabular}{cccccc}
\hline Sample & $\begin{array}{c}\text { \% Inhibition at } \\
62.500 \mu \mathrm{g}\end{array}$ & $\mathrm{IC}_{50(\mathrm{mg} / \mathrm{mL})}$ & $\mathrm{EC}_{50(\mathrm{mg} / \mathrm{mgABT})}$ & ARP & QEAC \\
& & ABTS & & & \\
MES & $85.272 \pm 5.446^{\mathrm{b}}$ & 0.029 & 0.372 & 269.151 & 2001.380 \\
MER & $7.488 \pm 0.988^{\mathrm{a}}$ & 0.814 & 10.436 & 9.582 & 71.253 \\
QR & $99.419 \pm 0.295^{\mathrm{c*}}$ & & & & \\
\hline
\end{tabular}

\#= \% inhibition at $18.890 \mu \mathrm{g} / \mathrm{mL}$. The values having different superscript (Small alphabet) letters within a column were significantly different $(p \leq 0.05)$.

Table 9: Correlation between TPC, TFC, DPPH, ABTS and FRAP values of MES and MER of Codonopsis clematidea.

\begin{tabular}{cccccc}
\hline & TPC & TFC & DPPH & ABTS & FRAP \\
\hline TPC & 1 & $0.994^{* *}$ & $0.988^{* *}$ & $0.991^{* *}$ & $0.961^{* *}$ \\
TFC & & 1 & $0.993^{* *}$ & $0.991^{* *}$ & $0.984^{* *}$ \\
DPPH & & & 1 & $0.995^{* *}$ & 0.983 \\
ABTS & & & & 1 & $0.980^{* *}$ \\
FRAP & & & & & 1 \\
\hline
\end{tabular}

**. Correlation is significant at the 0.01 level (2-tailed).

The present work also covers the identification of volatile compounds in MES and MER (Table 10; Figure 2). Gas chromatography with mass spectrometry has become the best technique for the analysis of volatile compounds of plant origin. ${ }^{51}$ Among the various identified compounds in MES, fatty acid and their derivatives cover $27.76 \%$ of the cluster, where in saturated fatty acid (SFA; $15.6 \%$, fatty acid methyl ester $(1.07 \%)$, unsaturated fatty acid (4.10\%) and fatty aldehyde (6.99\%) are present, followed by terpenoids (18.47\%) which includes acyclic diterpenoids (1.51\%), triterpenoids (15.67\%), sesquiterpenoids $(0.51 \%)$ and triterpene diketone $(0.78 \%)$ in its cluster. Other major classes viz. quinic acid derivative $(8.42 \%)$, cycloartanol derivative $(5.01 \%)$, tocopherol derivative $(0.68 \%)$, phenols $(6.78 \%)$, alkane $(0.26 \%)$, stigmastane $(3.24)$ and long chain hydrocarbons classes $(8.08 \%)$ of secondary metabolites are also found in MES, while the MER was rich in fatty acids and their derivatives with SFA (21.05\%), fatty acid methyl ester $(2.51 \%)$ and polyunsaturated fatty acid (PUFA; 7.57\%). Other identified classes were triterpenoid $(6.07 \%)$, hydroxypyrimidine $(3.09 \%)$, alcohol $(0.76 \%)$, alkaloid (1.52\%), cyclic diketone (5.28\%), aldehyde (4.89\%), sugar $(8.66 \%)$, alkyl halide $(0.44 \%)$, tocopherol derivative $(0.78 \%)$ and phenol $(4.4 \%)$

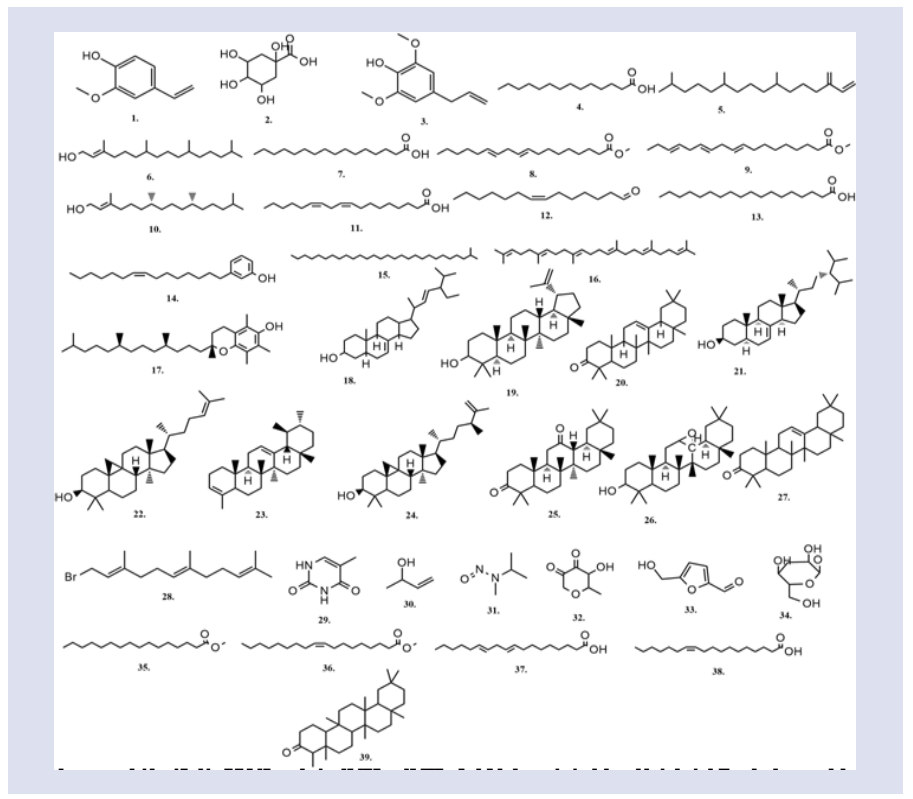

Figure 2: Structure of compounds identified in GC-MS analysis of MES and MER:- 1. 2-Methoxy-4-vinylphenol 2. 1, 3, 4, 5-Tetrahydroxycyclohexanecarboxylic acid 3. Phenol,2,6-dimethoxy-4-(2-propenyl)- 4. Tetradecanoic acid 5. Neophytadiene 6. 3,7,11,15-Tetramethyl-2-hexadecen-1-ol 7. n-Hexadecanoic acid 8. 9,12-Octadecadienoic acid, methyl ester 9. 9,12,15-Octadecatrienoic acid, methyl ester 10. 2-hexadecen-1-ol, 3,7,11,15-Tetramethyl-,[R$\left[R^{*} \cdot R^{*}\right.$-(E)]] 11. 9,12-Octadecadienoic acid (Z, Z)- 12. 7-Tetradecenal, (Z)- 13. Octadecanoic acid 14. (Z)-3-(pentadec-8-en-1-yl) phenol 15. 2-Methyloctacosane 16. Squalene 17. Vitamin E 18. Chondrillasterol 19. Lupeol 20. beta. -Amyrone 21. Stigmast-7-en-3-ol, (3.beta.,5.alpha.,24S) 22. 9,19-Cyclolanost-24-en-3-ol, (3.beta.)- 23. 24-Norursa-3,12-diene 24. 9,19-Cyclolanost-25-en-3-ol,24-methyl-, (3.beta.,24S)- 25. 3,12-Oleandione 26. (14. beta.)12,13-Epoxyolean-3-ol 27. 4,4,6a,6b,8a,11,11,14b-Octamethyl-1,4,4a, $5,6,6 \mathrm{a}, 6 \mathrm{~b}, 7,8,8 \mathrm{a}, 9,10,11,12,12 \mathrm{a}, 14,14 \mathrm{a}, 14 \mathrm{~b}$-octadecahydro-2H-picen3-one 28. Farnesyl bromide 29. Thymine 30. 3-Buten-2-ol 31. 2-Propanamine, n-methyl-n-nitroso 32. 1, 5-Anhydro-6-deoxyhexo-2, 3-diulose 33. 5-Hydroxymethylfurfural 34. 3-Deoxy-D-mannoic lactone 35. Hexadecanoic acid, methyl ester 36. 9-Octadecenoic acid (Z)-, methyl ester 37. Linoelaidic acid 38. cis-Vaccenic acid 39. Friedelan-3-one.

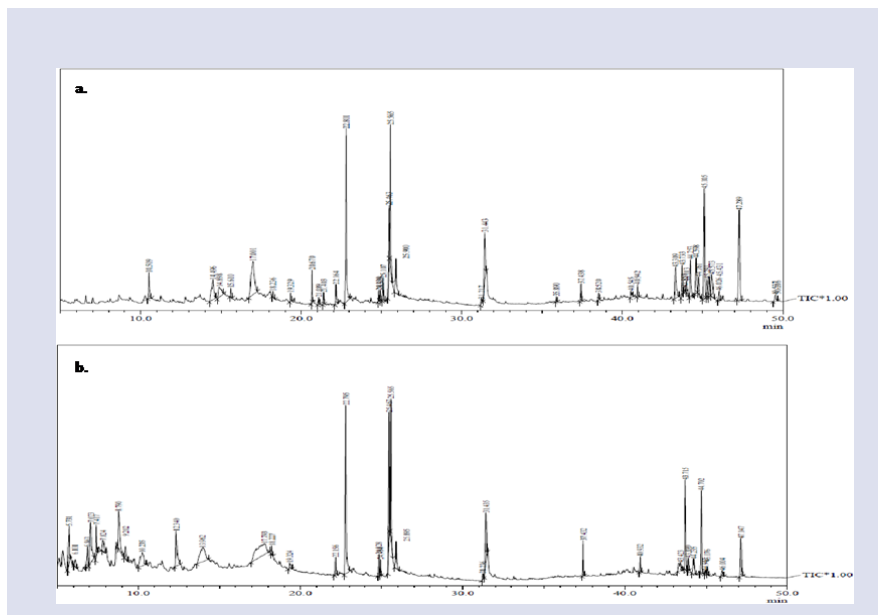

Figure 3: GC-MS Chromatogram: a) MES; b) MER of Codonopsis clematidea. 
Table 10: Compound identified in MES and MER of Codonopsis clematidea using GC-MS.

\begin{tabular}{|c|c|c|c|c|c|c|c|c|c|}
\hline \multicolumn{10}{|c|}{ Compounds identified in MES of Codonopsis clematidea } \\
\hline S.No. & \multicolumn{2}{|l|}{ Name } & Formula & M.W. & R.T. & $\%$ Area & CAS No. & S.I. & Compound Nature \\
\hline 1. & \multicolumn{2}{|l|}{ 2-Methoxy-4-vinylphenol } & $\mathrm{C}_{9} \mathrm{H}_{10} \mathrm{O}_{2}$ & 150 & 10.50 & 1.90 & $7786-61-0$ & 96 & Phenol \\
\hline 2. & \multicolumn{2}{|l|}{ 1,3,4,5-Tetrahydroxycyclohexanecarboxylic acid } & $\mathrm{C}_{7} \mathrm{H}_{12} \mathrm{O}_{6}$ & 192 & 17.00 & 8.42 & 77-95-2 & 93 & Quinic acid derivative \\
\hline 3. & \multicolumn{2}{|l|}{ Phenol,2,6-dimethoxy-4-(2-propenyl)- } & $\mathrm{C}_{11} \mathrm{H}_{14} \mathrm{O}_{3}$ & 194 & 18.23 & 0.37 & $6627-88-9$ & 80 & Phenol \\
\hline 4. & \multicolumn{2}{|l|}{ Tetradecanoic acid } & $\mathrm{C}_{14} \mathrm{H}_{28} \mathrm{O}_{2}$ & 228 & 19.32 & 0.51 & $544-63-8$ & 90 & Saturated fatty acid \\
\hline 5. & \multicolumn{2}{|l|}{ Neophytadiene } & $\mathrm{C}_{20} \mathrm{H}_{38}$ & 278 & 20.67 & 0.51 & $504-96-1$ & 95 & Sesquiterpenoids \\
\hline 6. & \multicolumn{2}{|l|}{ 3,7,11,15-Tetramethyl-2-hexadecen-1-ol } & $\mathrm{C}_{20} \mathrm{H}_{40} \mathrm{O}$ & 296 & 21.08 & 0.36 & $102608-53-7$ & 90 & Acyclic diterpenoids \\
\hline 7. & \multicolumn{2}{|l|}{ n-Hexadecanoic acid } & $\mathrm{C}_{16} \mathrm{H}_{32} \mathrm{O}_{2}$ & 256 & 22.80 & 12.58 & $57-10-3$ & 97 & Saturated fatty acid \\
\hline 8. & \multicolumn{2}{|l|}{ 9,12-Octadecadienoic acid, methyl ester } & $\mathrm{C}_{19} \mathrm{H}_{34} \mathrm{O}_{2}$ & 294 & 24.83 & 0.45 & $2462-85-3$ & 93 & Fatty acid methyl ester \\
\hline 9. & 9,12,15-Octadecatrienoic acid, methyl ester & & $\mathrm{C}_{19} \mathrm{H}_{32} \mathrm{O}_{2}$ & 292 & 24.92 & 0.62 & $7361-80-0$ & 87 & Fatty acid methyl ester \\
\hline 10. & 2-Hexadecen-1-ol, 3,7,11,15-Tetramethyl-, [R-[R*.R & E)]] & $\mathrm{C}_{20} \mathrm{H}_{40} \mathrm{O}$ & 296 & 25.10 & 1.15 & $150-86-7$ & 96 & Acyclic diterpenoids \\
\hline 11. & 9,12-Octadecadienoic acid (Z,Z)- & & $\mathrm{C}_{18} \mathrm{H}_{32} \mathrm{O}_{2}$ & 280 & 25.46 & 4.10 & $60-33-3$ & 95 & Unsaturated Fatty acid \\
\hline 12. & 7-Tetradecenal, (Z)- & & $\mathrm{C}_{14} \mathrm{H}_{26} \mathrm{O}$ & 210 & 25.56 & 6.99 & $65128-96-3$ & 88 & Fatty aldehyde \\
\hline 13. & Octadecanoic acid & & $\mathrm{C}_{18} \mathrm{H}_{36} \mathrm{O}_{2}$ & 284 & 25.90 & 2.51 & $57-11-4$ & 94 & Saturated fatty acid \\
\hline 14. & (Z)-3-(pentadec-8-en-1-yl)phenol & & $\mathrm{C}_{21} \mathrm{H}_{34} \mathrm{O}$ & 302 & 31.44 & 4.51 & $501-26-8$ & 90 & Phenol \\
\hline 15. & 2-Methyloctacosane & & $\mathrm{C}_{29} \mathrm{H}_{60}$ & 408 & 35.89 & 0.26 & $0-00-0$ & 92 & Alkane \\
\hline 16. & Squalene & & $\mathrm{C}_{30} \mathrm{H}_{50}$ & 410 & 37.43 & 0.84 & $111-02-4$ & 94 & Triterpenoid \\
\hline 17. & Vitamin E & & $\mathrm{C}_{29} \mathrm{H}_{50} \mathrm{O}_{2}$ & 92 & 40.94 & 0.68 & $59-02-9$ & 92 & Tocopherol derivative \\
\hline 18. & Chondrillasterol & & $\mathrm{C}_{29} \mathrm{H}_{48} \mathrm{O}$ & 412 & 43.30 & 3.24 & $481-17-4$ & 88 & Stigmastanes \\
\hline 19. & Lupeol & & $\mathrm{C}_{30} \mathrm{H}_{50} \mathrm{O}$ & 426 & 43.73 & 2.05 & $545-47-1$ & 80 & Triterpenoid \\
\hline 20. & beta.-Amyrone & & $\mathrm{C}_{30} \mathrm{H}_{48} \mathrm{O}$ & 424 & 44.01 & 1.04 & $638-97-1$ & 89 & Triterpenoid \\
\hline 21. & Stigmast-7-en-3-ol,(3.beta.,5.alpha.,24S) & & $\mathrm{C}_{29} \mathrm{H}_{50} \mathrm{O}$ & 414 & 44.25 & 3.30 & $18525-35-4$ & 88 & Triterpenoid \\
\hline 22. & 9, 19-Cyclolanost-24-en-3-ol,(3.beta.)- & & $\mathrm{C}_{30} \mathrm{H}_{50} \mathrm{O}$ & 426 & 44.59 & 2.41 & $469-38-5$ & 93 & Cycloartanol derivative \\
\hline 23. & 24-Norursa-3,12-diene & & $\mathrm{C}_{29} \mathrm{H}_{46}$ & 394 & 44.76 & 1.52 & 201358-25-0 & 84 & Triterpenoid \\
\hline 24. & 9,19-Cyclolanost-25-en-3-ol,24-methyl-,(3.beta., & & $\mathrm{C}_{31} \mathrm{H}_{52} \mathrm{O}$ & 440 & 45.57 & 2.60 & $511-61-5$ & 88 & Cycloartanol derivative \\
\hline 25. & 3,12-Oleandione & & $\mathrm{C}_{30} \mathrm{H}_{48} \mathrm{O}_{2}$ & 440 & 49.53 & 0.78 & $0-00-0$ & 80 & Triterpene Diketone \\
\hline 26. & (14.beta.)12,13-Epoxyolean-3-ol & & $\mathrm{C}_{32} \mathrm{H}_{52} \mathrm{O}_{3}$ & 484 & 51.64 & 5.62 & $0-00-0$ & 85 & Triterpenoid \\
\hline 27. & $\begin{array}{r}\text { 4,4,6a }, 6 \mathrm{~b}, 8 \mathrm{a}, 11,11,14 \mathrm{~b} \text {-Octamethyl-1,4,4a,5,6,6a,6b, } \\
10,11,12,12 \mathrm{a}, 14,14 \mathrm{a}, 14 \mathrm{~b} \text {-octadecahydro-2H-picen }\end{array}$ & $\begin{array}{l}8 \mathrm{a}, 9 \text {, } \\
\text { ne }\end{array}$ & $\mathrm{C}_{15} \mathrm{H}_{25} \mathrm{Br}$ & 424 & 45.43 & 1.30 & $0-00-0$ & 89 & Triterpenoid \\
\hline 28. & Farnesyl bromide & & $\mathrm{C}_{30} \mathrm{H}_{48} \mathrm{O}$ & 284 & 45.10 & 8.08 & $6874-67-5$ & 81 & Aliphatic \\
\hline & Compour & iden & fied in MER & of Codor & psis cle & atidea & & & \\
\hline S.No. & Name & For & & M.W. & R.T. & $\begin{array}{c}\% \\
\text { Area }\end{array}$ & CAS No. & S.I. & Compound Nature \\
\hline 1. & Thymine & $\mathrm{C}_{5} \mathrm{H}$ & $\mathrm{N}_{2} \mathrm{O}_{2}$ & 126 & 5.73 & 3.09 & $65-71-4$ & 91 & Hydroxypyrimidine \\
\hline 2. & 3-Buten-2-ol & & & 72 & 6.01 & 0.76 & $598-32-3$ & 93 & Alcohol \\
\hline 3. & 2-Propanamine,n-methyl-n-nitroso & $\mathrm{C}_{4} \mathrm{H}$ & $\mathrm{N}_{2} \mathrm{O}$ & 102 & 6.86 & 1.52 & $30533-03-5$ & 88 & Alkaloid \\
\hline 4. & 1,5-Anhydro-6-deoxyhexo-2,3-diulose & & & 144 & 7.07 & 5.28 & $0-00-0$ & 89 & Cyclic diketone \\
\hline 5. & 5-Hydroxymethylfurfural & & & 126 & 8.79 & 4.89 & $67-47-0$ & 94 & Aldehyde \\
\hline 6. & 3-Deoxy-D-mannoic lactone & $\mathrm{C}_{6} \mathrm{H}$ & & 162 & 17.79 & 8.66 & $0-00-0$ & 87 & Sugar \\
\hline 7. & Tetradecanoic acid & $\mathrm{C}_{14} \mathrm{I}$ & & 228 & 19.32 & 0.59 & $544-63-8$ & 92 & Saturated fatty acid \\
\hline 8. & 1-Bromo-3,7,11-trimethyl-dodeca-2,6,10-triene & $\mathrm{C}_{15} \mathrm{I}$ & & 284 & 45.07 & 0.44 & $544-63-8$ & 80 & Alkyl halide \\
\hline 9. & Hexadecanoic acid, methyl ester & $\mathrm{C}_{17} \mathrm{H}$ & & 270 & 22.15 & 0.95 & $112-39-0$ & 85 & Fatty acid methyl ester \\
\hline 10. & n-Hexadecanoic acid & $\mathrm{C}_{16} \mathrm{I}$ & & 256 & 22.79 & 11.86 & $57-10-3$ & 97 & Saturated fatty acid \\
\hline 11. & 9,12-Octadecadienoic acid, methyl ester & $\mathrm{C}_{19} \mathrm{H}$ & & 294 & 24.82 & 0.88 & $2462-85-3$ & 95 & Fatty acid methyl ester \\
\hline 12. & 9-Octadecenoic acid (Z)-, methyl ester & $\mathrm{C}_{19} \mathrm{I}$ & & 296 & 24.93 & 0.68 & $112-62-9$ & 91 & Fatty acid methyl ester \\
\hline 13. & Linoelaidic acid & $\mathrm{C}_{18} \mathrm{I}$ & & 280 & 25.46 & 7.57 & $506-21-8$ & 96 & $\begin{array}{l}\text { Poly unsaturated fatty } \\
\text { acid }\end{array}$ \\
\hline 14. & cis-Vaccenic acid & $\mathrm{C}_{18} \mathrm{H}$ & & 282 & 25.56 & 6.85 & $506-17-2$ & 95 & Saturated fatty acid \\
\hline 15. & Octadecanoic acid & $\mathrm{C}_{18} \mathrm{I}$ & & 284 & 25.89 & 1.75 & $57-11-4$ & 94 & Saturated fatty acid \\
\hline 16. & (Z)-3-(pentadec-8-en-1-yl)phenol & $\mathrm{C}_{21}$ & & 302 & 31.43 & 4.40 & $501-26-8$ & 90 & Phenol \\
\hline 17. & Squalene & & & 410 & 37.43 & 1.51 & $111-02-4$ & 97 & Triterpenoid \\
\hline 18. & Vitamin E & $\mathrm{C}_{29} \mathrm{I}$ & & 92 & 40.93 & 0.78 & $59-02-9$ & 93 & Tocopherol derivative \\
\hline 19. & Stigmast-7-en-3-ol,(3.beta.,5.alpha.,24S) & $\mathrm{C}_{29}$ & & 414 & 44.23 & 1.35 & $18525-35-4$ & 80 & Triterpenoid \\
\hline 20. & Friedelan-3-one & $\mathrm{C}_{30}$ & & 426 & 47.14 & 3.21 & $559-74-0$ & 94 & Triterpenoid \\
\hline
\end{tabular}

M.W. $=$ molecular weight, R.T. $=$ Retention time, S.I $=$ Similarity index. 
classes of secondary metabolites. The major identified compounds (S.I. $\geq 80 \%)$ in MES were $n$-hexadecanoic acid and franseyl bromide. $\mathrm{n}$-Hexadecanoic acid is well known for its biological potential viz. antioxidant, pesticide, hypocholesterolemic nematicide, 5-alpha-reductase inhibitor, lubricant, antiandrogenic, hemolytic, while farnesyl bromide does not have any known biological potential yet. ${ }^{52}$ In case of MER, the major constituents were n-hexadecanoic acid and 3-deoxy-D-mannoic lactone. 3-Deoxy-D-mannoic lactone is reported to have antifungal properties. ${ }^{53}$ From present results, it is evident that there is a high percentage of fatty acid and triterpenoids classes of secondary metabolites in case of MES. Some phenolic compounds were also reported which may contribute towards the antioxidant potential of the extract; whereas in MER, fatty acids are present as the key constituents. These identified components in different methanol extracts may be responsible for different biological activities of these extracts.

\section{CONCLUSION}

Codonopsis clematidea, a high altitude plant is found to have a profound potential to act as a source of supplements to survive in high altitude conditions. Carbohydrate profile of this plant demonstrated that roots are a rich source of sugar in comparison to stem and can act as an energy source. Further, among the various extraction techniques, soxhlet extraction provided the best extracted yield percentage. The phytochemical analysis of MES and MER obtained from stems and roots of Codonopsis clematidea revealed the presence of higher concentration of compounds with antioxidant ability in MES in comparison to MER. Thus, stems can serve as antioxidant supplements to combat the issue pertaining to the high altitude. Further, GC-MS analysis revealed the presence of fatty acid and terpenoids as their major fraction. However, there is also a need to understand the chemical composition of polar constituents in these extracts. Thus, future studies should be focused on the isolation, identification and characterization of bioactive compounds along with their in vivo safety studies, which are still warranted for investigation in experimental animal models prior to their practical application.

\section{ACKNOWLEDGEMENT}

The authors are highly thankful to DRDO for providing financial assistance to the research.

\section{CONFLICT OF INTEREST}

The authors declare no conflict of interest.

\section{ABBREVATIONS}

DMSO: Dimethyl sulfoxide; MES: Methanol extract of stems; MER: Methanol extract of roots; DES: Dimethyl sulfoxide extract of stems; DPE: Dry powder extract; min: Minutes; h: Hours; g: Gram; ROS: Reactive oxygen species.

\section{REFERENCE}

1. Ballabh B, Chaurasia OP. Medicinal plants of cold desert Ladakh used in the treatment of stomach disorders. IJTK. 2009;8(2):185-90.

2. Singh B, Chaurasia OP. Medicinal flora of Indian cold desert. XXV International Horticultural Congress, Part 13: New and specialized crops and products, botanic gardens and human-horticulture relationship. Brussels. 1998;65-74.

3. Kumar R, Thakur MS, Bhardwaj P, Bhardwaj G, Raghuvanshi R, Chaurasia OP. GC-MS profiling and bioactivity study of trans-himalayan plant Centaurea depressa. Der Pharma Chemica. 2017;9:63-9.

4. Choudhary A, Kumar R, Srivastava RB, Surapaneni SK, Tikoo K, Singh IP. Isolation and characterization of phenolic compounds from Rhodiola imbricata, a TransHimalayan food crop having antioxidant and anticancer potential. J Funct Foods. 2015;16:183-93

5. Bhardwaj P, Bhardwaj G, Raghuvanshi R, Thakur MS, Kumar R, Chaurasia OP. Rhodiola: An overview of phytochemistry and pharmacological applications. In:
Singh B, Peter KV. New Age Herbals $1^{\text {st }}$ ed. Singapore: Springer. 2018;71-113.

6. Aripova SF. Alkaloid content of Codonopsis clematidea. Chem Nat Compd. 1996;32(4):564-5

7. He JY, Ma N, Zhu S, Komatsu K, Li ZY, Fu WM. The genus Codonopsis (Campanulaceae): a review of phytochemistry, bioactivity and quality control. J Nat Med. 2015;69(1):1-21.

8. Ishida S, Okasaka M, Ramos F, Kashiwada Y, Takaishi Y, Kodzhimatov OK, et al. New alkaloid from the aerial parts of Codonopsis clematidea. J Nat Med. 2008;62(2):236-8.

9. Tashkhodzhaev B, Aripova SF, Turgunov KK, Abdilalimov O. Stereochemistry of the alkaloids codonopsine and codonopsinine. Chem Nat Compd. 2004;40(6):618-9.

10. Wakana D, Kawahara N, Goda Y. Two new pyrrolidine alkaloids, codonopsinol $\mathrm{C}$ and codonopiloside $\mathrm{A}$, isolated from Codonopsis pilosula. Chem Pharm Bull. 2013;61(12):1315-7.

11. Chaurasia OP, Ahmed Z, Ballabh B. Ethnobotany and plants of trans-Himalaya. Satish Serial Pub. House. 2007.

12. Puchkova VB. The pharmacodynamics of natural and synthetic drugs of Kazakhastan [in Rassia]. 1964

13. Xu GJ, Xu LS, Wang ZT. Species systematization and quality evaluation of commonly used Chinese traditional drugs (South-China Edition). Fujian Science and Technology Press, Fuzhou. 1997;4:658.

14. Gulcin I, Buyukokuroglu ME, Oktay M, Kufrevioglu OI. Antioxidant and analgesic activities of turpentine of Pinus nigra Arn. subsp. pallsiana (Lamb.) Holmboe. J Ethnopharmacol. 2003;86(1):51-8.

15. Kumar J, Dhar P, Tayade AB, Gupta D, Chaurasia OP, Upreti DK, et al. Antioxidant capacities, phenolic profile and cytotoxic effects of saxicolous lichens from trans-Himalayan cold desert of Ladakh. PLoS One. 2014;9(6):e98696.

16. Sharma P, Jha AB, Dubey RS, Pessarakli M. Reactive oxygen species, oxidative damage and antioxidative defense mechanism in plants under stressful conditions. J Bot. 2012;2012:26. doi:10.1155/2012/217037

17. Halliwell B. Free radicals, antioxidants and human disease: curiosity, cause or consequence?. The Lancet. 1994;344(8924):721-4

18. Halliwell B, Gutteridge J. Oxygen toxicity, oxygen radicals, transition metals and disease. Biochem J. 1984;219(1):1.

19. Aruoma Ol. Free radicals, oxidative stress and antioxidants in human health and disease. J Am Oil Chem Soc. 1998;75(2):199-12.

20. Zhang W, Li B, Han L, Zhang H. Antioxidant activities of extracts from Areca (Areca catectu L.) flower, husk and seed. Afr J Biotechnol. 2009;8(16):3887-92.

21. Buyukokuroglu ME, Gulcin I, Oktay M, Kufrevioglu OI. In vitro antioxidant properties of dantrolene sodium. Pharmacol Res. 2001;44(6):491-4.

22. Sumanta N, Haque Cl, Nishika J, Suprakash R. Spectrophotometric analysis of chlorophylls and carotenoids from commonly grown fern species by using various extracting solvents. Res J Chem Sci. 2014;4(9):63-9.

23. Porra RJ, Thompson WA, Kriedemann PE. Determination of accurate extinction coefficients and simultaneous equations for assaying chlorophylls a and b extracted with four different solvents: verification of the concentration of chlorophyll standards by atomic absorption spectroscopy. Biochim Biophys Acta Bioenerg. 1989;975(3):384-94.

24. Ranganna S. Proximate constituents. In: Handbook of analysis and quality control for fruit and vegetable products, $2^{\text {nd }}$ ed. New Delhi: McGraw Hill Education India Pvt Ltd. 1986;1-30.

25. Karabegovic IT, Stojicevic SS, Velickovic DT, Todorovic ZB, Nikolic NC, Lazic ML. The effect of different extraction techniques on the composition and antioxidant activity of cherry laurel (Prunus laurocerasus) leaf and fruit extracts. Ind Crops Prod. 2014;54:142-8.

26. Sharma A, Cannoo DS. A comparative study of effects of extraction solvents/ techniques on percentage yield, polyhenolic composition and antioxidant potential of various extracts obtained from stems of Nepeta leucophylla: RP-HPLC-DAD assessment of its polyhenolic constituents. J Food Biochem. 2017;41(2):e12337.

27. Stoilova I, Krastanov A, Stoyanova A, Denev P, Gargova S. Antioxidant activity of a ginger extract (Zingiber officinale). Food Chem. 2007;102(3):764-70.

28. Bhardwaj G, Cameotra SS, Chopra HK. Biosurfactant from Lysinibacillus chungkukjangi from rice bran oil sludge and potential applications. J Surfactants Deterg. 2016;19(5):957-65.

29. Dhar P, Bajpai PK, Tayade AB, Chaurasia OP, Srivastava RB, Singh SB. Chemical composition and antioxidant capacities of phytococktail extracts from transHimalayan cold desert. BMC Complement Altern Med. 2013;13(1):259-89.

30. Lim CS, Lim SL. Ferric reducing capacity versus ferric reducing antioxidant power for measuring total antioxidant capacity. Laboratory Medicine. 2013;44(1):51-5.

31. Sharma A, Cannoo DS. Comparative evaluation of extraction solvents/techniques for antioxidant potential and phytochemical composition from roots of Nepeta leucophylla and quantification of polyphenolic constituents by RP-HPLC-DAD. J Food Meas Charact. 2016;10(3):658-69

32. Anderson JM. Consequences of spatial separation of photosystem 1 and 2 in thylakoid membranes of higher plant chloroplasts. FEBS Lett. 1981;124(1):1-10 
33. Lichtenthaler HK. [34] Chlorophylls and carotenoids: pigments of photosynthetic biomembranes. Methods in enzymology: Plant Cell Membranes, $1^{\text {st }}$ ed. Cambridge: Academic Press. 1987;148:350-82.

34. Zhang $H$, Zhong $H$, Wang J, Sui $X, X u N$. Adaptive changes in chlorophyll content and photosynthetic features to low light in Physocarpus amurensis Maxim and Physocarpus opulifolius “Diabolo". Peer J. 2016;4:e2125.

35. Melis A, Harvey GW. Regulation of photosystem stoichiometry, chlorophyll a and chlorophyll b content and relation to chloroplast ultrastructure. Biochim Biophys Acta Bioenerg. 1981;637(1):138-45.

36. Caffarri S, Tibiletti T, Jennings CR, Santabarbara S. A comparison between plant photosystem I and photosystem I| architecture and functioning. Curr Protein Pept Sci. 2014;15(4):296-31.

37. Armstrong GA, Hearst JE. Carotenoids 2: Genetics and molecular biology of carotenoid pigment biosynthesis. FASEB J. 1996;10(2):228-37.

38. Bernstein PS, Li B, Vachali PP, Gorusupudi A, Shyam R, Henriksen BS, et al. Lutein, zeaxanthin and meso-zeaxanthin: the basic and clinical science underlying carotenoid-based nutritional interventions against ocular disease. Prog Retin Eye Res. 2016;50:34-66.

39. Cataldi TR, Margiotta G, lasi L, Di Chio B, Xiloyannis C, Bufo SA. Determination of sugar compounds in olive plant extracts by anion-exchange chromatography with pulsed amperometric detection. Anal Chem. 2000;72(16):3902-7.

40. Wang $L$, Weller $C L$. Recent advances in extraction of nutraceuticals from plants Trends Food Sci Technol. 2006;17(6):300-12.

41. Hayouni EA, Abedrabba M, Bouix M, Hamdi M. The effects of solvents and extraction method on the phenolic contents and biological activities in vitro of Tunisian Quercus coccifera L. and Juniperus phoenicea L. fruit extracts. Food Chem. 2007;105(3):1126-34

42. Vinatoru M. An overview of the ultrasonically assisted extraction of bioactive principles from herbs. Ultrason Sonochem. 2001;8(3):303-13.
43. Shahidi F, Janitha PK, Wanasundara PD. Phenolic antioxidants. Crit Rev Food Sci Nutr. 1992;32(1):67-103

44. Hosseinimehr SJ. Trends in the development of radioprotective agents. Drug Discov Today. 2007;12(19-20):794-805

45. Kaur T, Hussain K, Koul S, Vishwakarma R, Vyas D. Evaluation of nutritional and antioxidant status of Lepidium latifolium Linn.: a novel phytofood from Ladakh. PLoS One. 2013;8(8):e69112.

46. Hong $Y$, Lin $S$, Jiang $Y$, Ashraf $M$. Variation in contents of total phenolics and flavonoids and antioxidant activities in the leaves of 11 Eriobotrya species. Plant Foods Hum Nutr. 2008;63(4):200.

47. Kessler M, Ubeaud G, Jung L. Anti- and pro-oxidant activity of rutin and quercetin derivatives. J Pharm Pharmacol. 2003;55(1):131-42.

48. Lebeau J, Furman C, Bernier JL, Duriez P, Teissier E, Cotelle N. Antioxidant properties of di-tert-butylhydroxylated flavonoids. Free Radic Biol Med. 2000;29(9):900-12.

49. Re R, Pellegrini N, Proteggente A, Pannala A, Yang M, Rice-Evans C. Antioxidan activity applying an improved ABTS radical cation decolorization assay. Free Radic Biol Med. 1999;26(9-10):1231-7.

50. Ou B, Huang D, Hampsch-Woodill M, Flanagan JA, Deemer EK. Analysis of antioxidant activities of common vegetables employing Oxygen Radical Absorbance capacity (ORAC) and Ferric Reducing Antioxidant Power (FRAP) assays: a comparative study. J Agric Food Chem. 2002;50(11):3122-8.

51. Jadhav $V$, Kalase V, Patil P. GC-MS analysis of bioactive compounds in methanolic extract of Holigarna grahamii (wight) Kurz. IJHM. 2014;35(24):35-9.

52. Rajeswari G, Murugan M, Mohan VR. GC-MS analysis of bioactive components of Hugonia mystax L. (Linaceae). Res J Pharm Biol Chem Sci. 2012;3(4):301-18.

53. Sharma MD, Rautela I, Sharma N, Gahlot M, Koshy EP. GC-MS analysis of phytocomponents in juice sample of Indian cane: Saccharum barberi. Int J Pharm Sci Res. 2015;6:5147-3

\section{GRAPHICAL ABSTRACT}
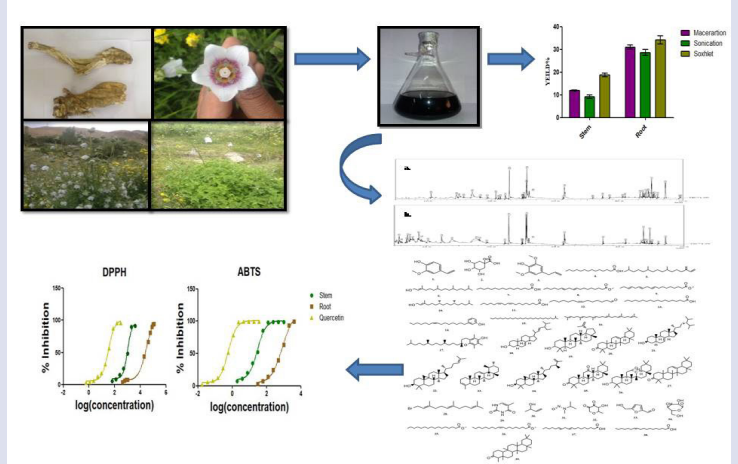

\section{SUMMARY}

- To the best of our knowledge, this is the first report which covers chlorophylls, carbohydrates, GC-MS analysis, TPC, TFC and antioxidant activity of methanol extracts obtained from stems and roots of Codonopsis clematidea. The study clearly showed the soxhlet, as the best extraction technique with high yield efficiency. In addition to this, chlorophyll analysis of stem revealed the presence of higher amount of $\mathrm{Ch}_{\text {a. }}$ Carbohydrate analysis showed the presence of higher amount of sugar in roots in comparison to stem. GC-MS analysis of MES and MER has showed the presence of different classes of secondary metabolites viz. fatty acid, terpenoids, quinic acid derivative, cycloartanol derivative, tocopherol derivative phenols, alkane, stigmastane, aliphatic, hydroxypyrimidine, alcohol, alkaloid, cyclic diketone, aldehyde, sugar, alkyl halide and tocopherol derivative. MES has a higher antioxidant value in comparison to root which correlates with TPC and TFC values of their respective extracts. The study concludes that stems of Codonopsis clematidea has a good potential to act as a source of antioxidant and can be considered for the further study for the isolation and identification of biologically potent compounds.

\section{ABOUT AUTHORS}

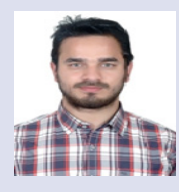

Pushpender Bhardwaj is working as Senior Research Fellow and Ph.D scholar in the Medicinal Plant Division, Defence Institute of High Altitude Re $\neg$ search, Leh. He is currently works on a project entitled 'Phytochemical profiling and Bioactivity study of Codonopsis clematidea of transhimalayan Leh-Ladakh region'. He holds M.Sc in Molecular Biology and Biotechnology from Tezpur Univerity, Assam.

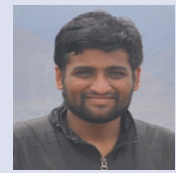

Sahil Kapoor is Pursuing his Ph.D from Jaypee University of Information Technology, Himachal Pradesh.

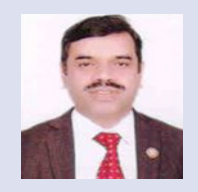

Om Prakash Chaurasia is working as Scientist ' $G$ ' and Director, Defence Institute of High Altitude Research, Leh. He obtained his Ph.D degree in Botany from Magadh University Bodh Gaya, Bihar in 1992. He has extensively surveyed trans-himalayan belts of Ladakh and Lahaul-Spiti and documented the fragile plant biodiversity and its ethnobotanical wealth. Two Research Fellows have been awarded Ph.D. under his supervision.

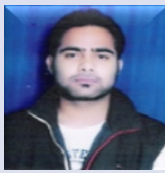

Ashwani Kumar Bhardwaj has Submitted his Ph.D thesis in Bharthiar University, Coimbatore. 


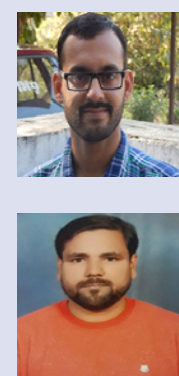

Ajay Sharma is Pursuing his Ph.D from Sant Longowal Institute of Engineering and Technology, Sangrur, Punjab.

Mohan Singh Thakur is working as Technical Officer ' $A$ ' in the Medicinal Plant Division of Defence Institute of High Altitude Re-search, Leh.

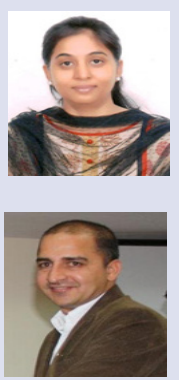

Shweta Saxena is working as Scientist ' $E$ ' and Head, Medicinal Plant Division at Defence Institute of High Altitude Research, Leh.

Rajkumar is working as Scientist ' $D$ ' in Medicinal Plant Division, Defence Institute of High Altitude Re $\neg$ search, Leh. He obtained his M.Sc degree in Chemistry from Rajasthan University, Jaipur in 2004.

Cite this article: Bhardwaj P, Thakur MS, Kapoor S, Bhardwaj AK, Sharma A, Saxena S, Chaurasia OP, kumar R. Phytochemical Screening and Antioxidant Activity Study of Methanol Extract of Stems and Roots of Codonopsis clematidea from Trans-himalayan Region. Pharmacog J. 2019;11(3):536-46. 